\title{
ANALISIS PENYAJIAN LAPORAN KEUANGAN KOPERASI SYARIAH (STUDI KASUS PADA BMT MUDA DAN KJKS BMT AMANAH UMMAH DI SURABAYA)'
}

\author{
Nabilah \\ Program Studi S-1 Ekonomi Islam - Fakultas Ekonomi dan Bisnis - Universitas \\ Airlangga \\ Email: nabilahamini@gmail.com
}

Noven Suprayogi

Departemen Ekonomi Syariah-Fakultas Ekonomi dan Bisnis-Universitas Airlangga

Email: noven.suprayogi@feb.unair.ac.id

\begin{abstract}
:
Sharia cooperative is subject to use the PSA Sharia guideline 100 and 101 on the process of arranging and presenting financial report. The fact is that there are a lot of financial report presentation that is less suitable with the PSAK Sharia. This research aims at determining the reasons why do the financial report presentation is less suitable with the PSAK Sharia 100 and 101.

This research utilizes qualitative approach with exploratory case study method. Data collection is done by interviewing informant with resource triangulation validation method.

The result of this research shows that sharia cooperation tends to use Indonesian Accounting Standards Non-Publicly-Accountable Entities (SAK ETAP) when presenting the financial report since there is a Ministrial regulation of Cooperatives and SmallMedium Enterprises number 4 in

2012 that obliged all the cooperatives in Indonesia to use SAK ETAP guide.
\end{abstract}

Keywords: Financial Report, Accounting Standards Applicable in Indonesia, PSAK Sharia 100, PSAK Sharia 101

\section{PENDAHULUAN Latar Belakang}

Koperasi syariah atau yang sering disebut Koperasi Jasa Keuangan Syariah (KJKS) adalah koperasi yang kegiatan usahanya bergerak di bidang pembiayaan, investasi, dan simpanan sesuai pola syariah. Munculnya jenis koperasi ini berawal dari Keputusan Menteri Negara Koperasi dan Usaha Kecil dan Menengah RI Nomor: 91/Kep/M.KUKM/IX/2004 tentang petunjuk pelaksanaan kegiatan usaha koperasi syariah.

Pemerintah melalui departemen koperasi telah membuat Standar Operasional Prosedur (SOP) untuk menjaga kesesuaian syariah dalam 1) Jurnal ini merupakan bagian dari skripsi Nabilah, NIM: 041014033, yang diuji pada 1 Februari 2016 praktek koperasi syariah. SOP tersebut terbagi dalam tiga bagian Standar Operasional Manajemen (SOM), yaitu standar operasi manajemen kelembagaan, manajemen usaha, dan manajemen keuangan Koperasi Jasa Keuangan Syariah (KJKS) dan Unit Jasa Keuangan Syariah (UJKS). Aturan ini dijelaskan dalam Peraturan Menteri Negara Koperasi dan Usaha Kecil dan Menengah RI nomor 35 tahun 2007.

Standar operasional manajemen keuangan KJKS dan UJKS terkandung standar akuntansi keuangan untuk KJKS dan UJKS yang mengacu pada Pernyataan Standar Akuntansi 
Nabilah, et al/Jurnal Ekonomi Syariah Teori dan Terapan Vol. 3 No. 10 Oktober 2016: 843-855; ANALISIS PENYAJIAN LAPORAN KEUANGAN KOPERASI SYARIAH (Studi Kasus Pada BMT MUDA dan KJKS BMT Amanah Ummah di Surabaya)

Kevangan (PSAK) nomor 27 tentang akuntansi perkoperasian yang mulai tahun 2011 berubah menjadi Standar Akuntansi Keuangan Entitas Tanpa Akuntabilitas

Publik (SAK ETAP), PSAK Syariah, dan Keputusan Menteri Negara Koperasi dan Usaha Kecil dan Menengah RI nomor 91 tahun 2004 tentang petunjuk pelaksanaan kegiatan usaha koperasi syariah.

PSAK Syariah adalah hasil dari perubahan PSAK 59 tentang Akuntansi Perbankan Syariah yang disahkan oleh Dewan Standar Akuntansi Syariah (DSAS) pada tahun 2007 dan berlaku pada tahun buku 2008. Faktanya, penerapan PSAK Syariah pada KJKS masih belum maksimal karena masih banyak ditemukan KJKS yang melakukan kesalahan dalam pencatatan akuntansinya. Hal ini diperkuat oleh hasil penelitian yang dilakukan oleh Sari (2014), berjudul Analisis Struktur dan Komponen Keuangan KJKS UGT Sidogiri Wirolegi, menunjukkan bahwa laporan keuangan yang dibuat oleh pihak KJKS UGT Sidogiri Wirolegi belum sesuai dengan SAK ETAP dan PSAK Syariah, seperti ketidaksesuaian penyusunan laporan neraca dengan SAK ETAP dan PSAK Syariah, ketidaksesuaian arus kas dengan PSAK Syariah, dan belum tersusunnya laporan perubahan ekuitas, laporan sumber dan penggunaan dana zakat serta laporan sumber dan penggunaan dana kebajikan. Hasil penelitian lain yang dilakukan oleh
Sholihah (2009), berjudul Analisis Penerapan PSAK No

101-106 dalam Akuntansi Syariah (Studi Kasus KJKS An-Nisa Kabupaten Pemalang), menunjukkan bahwa PSAK No 101-106 belum sempurna diterapkan oleh KJKS An- Nisa, seperti mereka hanya menyusun laporan neraca, laporan laba rugi, laporan arus kas, laporan perubahan ekuitas, serta laporan sumber dan penggunaan dana kebajikan. Di samping itu, hasil dari kegiatan "Pendampingan Penerapan Akuntansi dan Pelaporan Keuangan Koperasi Jasa Keuangan Syariah/Unit Jasa Kevangan Syariah Berbasis Pernyataan Standar Akuntansi Keuangan (PSAK) Syariah" pada tahun 2014 oleh Dinas Koperasi dan UMKM Jatim bekerja sama dengan Lembaga Pengembangan Ekonomi Pembangunan (LPEP) FEB Unair, menunjukkan bahwa masih banyak KJKS dan UJKS yang belum sempurna dalam menerapkan PSAK Syariah.

Penelitian ini bertujuan untuk menjelaskan tentang alasan kurang sesuainya penyajian laporan kevangan dengan PSAK Syariah 100 dan 101.

Berdasarkan uraian di atas, rumusan masalah dari penelitian ini adalah mengapa penyajian laporan kevangan koperasi syariah kurang sesuai dengan PSAK Syariah 100 dan 101.

\section{LANDASAN PUSTAKA}

Menurut Buchori (2009:15) koperasi syariah adalah sebuah konversi dari koperasi konvensional melalui 
pendekatan yang sesuai dengan syariat Islam dan peneladanan ekonomi yang dilakukan Rasulullah dan para sahabatnya. Tujuan dari sistem koperasi syariah menurut Buchori (2009:18) adalah:

a. Mensejahterakan ekonomi anggotanya sesuai norma dan moral Islam.

b. Menciptakan persaudaraan dan keadilan sesame anggota

c. Pendistribusian pendapatan dan kekayaan yang merata sesama anggota berdasarkan kontribusinya.

d. Kebebasan pribadi dalam kemaslahatan sosial yang didasarkan pada pengertian bahwa manusia diciptakan hanya untuk tunduk kepada Allah.

Saat ini telah ada beberapa peraturan pemerintah yang mengatur tentang koperasi syariah, yaitu:

a. Undang-undang nomor 25 tahun 1992 tentang perkoperasian.

b. Peraturan Pemerintah nomor 9 tahun 1995 tentang pelaksanaan kegiatan usaha simpan pinjam oleh koperasi.

c. Keputusan Menteri Negara Koperasi dan UKM nomor 91 tahun 2004 tentang petunjuk pelaksanaan kegiatan usaha koperasi jasa kevangan syariah.

d. Peraturan Menteri Negara Koperasi dan UKM RI nomor 35 tahun 2007 tentang pedoman penilaian kesehatan koperasi jasa keuangan syariah dan unit jasa keuangan syariah koperasi.

e. Peraturan Menteri Negara Koperasi dan UKM RI nomor 19 tahun 2007 tentang pedoman pengawasan koperasi jasa keuangan syariah dan unit jasa keuangan syariah koperasi.

f. Peraturan Menteri Negara Koperasi dan
UKM RI nomor 4 tahun 2012 tentang pedoman umum akuntansi koperasi.

Bangun prinsip akuntansi syariah menurut Wiroso (2011: 20) terdiri dari tiga landasan yaitu:

Landasan syariah bersumber dari

Al-Qur'an, Al-Hadits, dan Fatwa Syariah. Landasan konseptual bersumber dari Kerangka Dasar Penyusunan dan Penyajian

Laporan Keuangan Syariah (KDPPLKS). Landasan operasional atau praktek terdiri dari tiga tingkatan yaitu: (a) tingkat satu bersumber dari PSAK dan ISAK syariah serta PSAK dan ISAK umum,

(b) tingkat dua bersumber dari SAK

internasional negara lain yang sesuai syariah, buletin tehnis, peraturan pemerintah untuk industri (regulasi), serta pedoman atau praktek akuntansi industri (kajian asosiasi syariah), (c) tingkat tiga bersumber dari praktek, konvensi dan kebiasaan pelaporan yang sehat sesuai dengan syariah, serta buku teks/ajar, simpulan riset, artikel, dan pendapat ahli.

Wiroso (2011:21) menjelaskan bahwa:

Bangun prinsip akuntansi

syariah

digambarkan sebagai suatu bangunan rumah 'Prinsip Akuntansi Syariah yang Berlaku Umum di Indonesia' dimana setiap lapisan di bawahnya menjadi landasan bagi lapisan di atasnya.

Standar akuntansi keuangan atau SAK merupakan konsensus pada kala itu tentang pencatatan sumber-sumber ekonomi, kewajiban, modal, hasil, biaya, dan perubahannya dalam bentuk laporan kevangan (Harahap, 2011: 153). 
Dengan adanya rencana IAI untuk mengadopsi semua IFRS, maka standar akuntansi di Indonesia terbagi menjadi empat, yaitu:

a. Standar akuntansi umum yang akan mengadopsi IFRS dan hanya berlaku wajib bagi perusahaan publik atau Tbk.

b. Standar akuntansi ETAP atau Entitas Tanpa Akuntabilitas Publik.

c. Standar akuntansi syariah yang berlaku untuk semua transaksi yang dilakukan secara syariah oleh lembaga dan pihak manapun.

d. Standar akuntansi pemerintahan atau SAP yang digunakan dalam lingkungan entitas pemerintah.

Standar Akuntansi Keuangan Entitas Tanpa Akuntabilitas Publik atau SAK ETAP digunakan untuk entitas tanpa akuntabilitas publik.

Unsur laporan keuangan yang tercantum dalam SAK ETAP meliputi: laporan neraca, laporan laba-rugi, laporan perubahan ekuitas, laporan arus kas, dan catatan atas laporan keuangan (IAI, 2009:17).

Untuk menjaga kesesuaian akuntansi syariah pada entitas syariah maka Ikatan Akuntansi Indonesia (IAI) sebagai Badan Penyusun Standar Akuntansi Indonesia melalui Dewan Standar Akuntansi Keuangan (DSAK), mengeluarkan Pernyataan Standar Akuntansi Keuangan (PSAK) nomor 59 pada tahun 2007. PSAK ini hanya berlaku untuk perbankan syariah sehingga pada tahun 2008 DSAK membentuk Komite Akuntansi Syariah (KAS) yang bertugas untuk melakukan perubahan PSAK 59 untuk disempurnakan menjadi PSAK syariah. Isi PSAK Syariah terdiri dari: PSAK 101 tentang penyajian laporan keuangan syariah, PSAK 102 tentang akuntansi murabahah, PSAK 103 tentang akuntansi salam, PSAK 104 tentang akuntansi istishna', PSAK 105 tentang akuntansi mudharabah, PSAK 106 tentang akuntansi musyarakah, PSAK 107 tentang akuntansi ijarah, PSAK 108 tentang akuntansi transaksi asuransi syariah, PSAK 109 tentang akuntansi zakat, infak, shadaqah, PSAK 110 tentang akuntansi sukuk (Wiroso, 2011: 1819).

Konsep laporan kevangan koperasi syariah berlandaskan PSAK 100-101. PSAK

100 berisi Kerangka Dasar Penyusunan dan Penyajian Laporan Kevangan Syariah (KDPPLKS) sedangkan PSAK 101 berisi penyajian laporan keuangan syariah.

Unsur-unsur laporan keuangan entitas syariah menurut IAI (2009: 23) terdiri dari:

a. Komponen laporan keuangan yang mencerminkan kegiatan komersial, terdiri dari: laporan posisi keuangan, laporan laba rugi, laporan arus kas, dan laporan perubahan ekuitas.

b. Komponen laporan keuangan yang mencerminkan kegiatan sosial, terdiri dari: laporan sumber dan penggunaan dana zakat serta laporan sumber dan penggunaan dana kebajikan.

c. Komponen laporan kevangan lainnya yang mencerminkan kegiatan dan tanggung jawab khusus entitas syariah tersebut. Unsur yang berkaitan secara langsung 
dengan pengukuran posisi keuangan adalah aset, kewajiban, dana syirkah temporer, dan ekuitas (IAI, 2009: 100.24).

Struktur dan isi laporan laba rugi menurut PSAK Syariah 101 sebagai berikut (IAl, 2009: 101.18-101.19):

a. Laporan laba rugi entitas syariah disajikan sedemikian rupa yang menonjolkan berbagai unsur kinerja keuangan yang diperlukan bagi penyajian secara wajar.

b. Laporan laba rugi minimal mencakup pos-pos berikut: pendapatan usaha, bagi hasil untuk pemilik dana, beban usaha, laba atau rugi usaha, pendapatan dan beban non

usaha, laba atau rugi dari aktivitas normal, beban pajak, dan laba atau rugi bersih untuk periode berjalan.

c. Jika terdapat pendapatan non halal maka pendapatan tersebut tidak boleh disajikan di dalam laporan laba rugi entitas syariah maupun laba rugi konsolidasian entitas konvensional yang mengkonsolidasikan entitas

syariah. Informasi pendapatan non halal tersebut disajikan dalam laporan sumber dan penggunaan dana kebajikan.

Laporan arus kas melaporkan arus kas selama periode tertentu dan diklasifikasi menurut aktivitas operasi, investasi, dan pendanaan (Wiroso, 2011 : 62).

Laporan perubahan ekuitas menggambarkan peningkatan atau penurunan aset bersih atau kekayaan selama periode bersangkutan berdasarkan prinsip pengukuran tertentu yang dianut dan harus diungkapkan dalam laporan keuangan (Wiroso, 2011: 65).

Struktur dan isi laporan sumber dan penggunaan dana zakat menurut PSAK Syariah 101 adalah (IAI, 2009:

101.
21):

a. Dana zakat yang berasal dari wajib zakat (muzakki). Dana ini bisa berasal dari dalam entitas syariah maupun dari luar entitas syariah.

b. Penggunaan dana zakat melalui lembaga amil zakat untuk fakir, miskin, riqab, orang yang terlilit hutang (gharim), muallaf, fi sabilillah, orang yang dalam perjalanan (ibnu sabil), dan amil.

c. Kenaikan atau penurunan dana zakat.

d. Saldo awal dana zakat. e. Saldo akhir dana zakat.

Struktur dan isi laporan sumber dan penggunaan dana kebajikan menurut PSAK Syariah 101 sebagai berikut (IAl, 2009:

101.22-101.23):

a. Sumber dana kebajikan yang berasal dari: infak, sedekah, hasil pengelolaan wakaf sesuai dengan perundang-undangan yang berlaku, pengembalian dana kebajikan produktif, denda, dan pendapatan non halal.

b. Penggunaan dana kebajikan untuk dana kebajikan produktif, sumbangan, dan penggunaan lainnya untuk kepentingan umum.

c. Kenaikan atau penurunan sumber dana kebajikan.

d. Saldo awal dana penggunaan dana kebajikan.

e. Saldo akhir dana penggunaan dana kebajikan.

Kerangka berpikir dari penelitian ini sebagai berikut: 


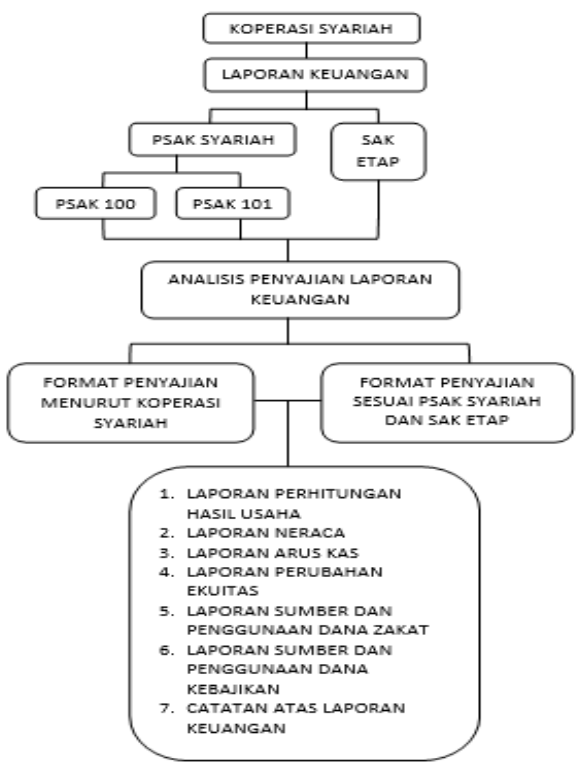

Gambar 1. Kerangka

Berpikir

\section{METODE PENELITIAN}

Penelitian ini menggunakan pendekatan kualitatif. Menurut Sugiyono (2014:1) metode penelitian kualitatif adalah:

Metode penelitian yang digunakan untuk meneliti pada kondisi obyek yang alamiah, (sebagai lawannya adalah eksperimen) dimana peneliti adalah sebagai instrumen kunci, teknik pengumpulan data dilakukan secara triangulasi (gabungan), analisis data bersifat induktif, dan hasil penelitian kualitatif lebih menekankan makna daripada generalisasi.

Penggunaan pendekatan kualitatif dimaksudkan untuk menjawab pertanyaan yang terdapat pada rumusan masalah yaitu mengapa penyajian laporan keuangan koperasi syariah kurang sesuai dengan PSAK Syariah 100 dan 101, sehingga diperoleh gambaran yang akurat dan mendalam tentang objek penelitian.

Metode penelitian yang digunakan adalah metode studi kasus eksploratoris. Menurut Yin ( 2011 :1) studi kasus adalah:

Strategi yang lebih cocok bila pokok pertanyaan suatu penelitian berkenaan dengan how atau why, bila peneliti hanya memiliki sedikit peluang untuk mengontrol peristiwa-peristiwa yang akan diselidiki, dan bilamana fokus penelitiannya terletak pada fenomena kontemporer (masa kini) di dalam konteks kehidupan nyata. Ruang lingkup penelitian ini berkaitan dengan rumusan masalah mengapa penyajian laporan keuangan koperasi syariah kurang sesuai dengan PSAK Syariah

100 dan

101.

Jenis dan sumber data yang digunakan dalam penelitian ini ada dua yaitu data primer dan data sekunder. Data primer diperoleh dari hasil wawancara dengan Koperasi Jasa Kevangan Syariah (KJKS) sebagai praktisi, dosen FEB Unair sebagai akademisi, Dinas Koperasi dan UMKM sebagai regulator, dan Ikatan Akuntan Indonesia (IAl) sebagai penyusun standar akuntansi. Data sekunder diperoleh dari laporan keuangan dan peraturan koperasi syariah.

Teknik pengumpulan data dalam penelitian ini menggunakan teknik wawancara. Jenis wawancara yang digunakan adalah wawancara mendalam (in-depth interview) yang bertujuan "menemukan permasalahan secara lebih terbuka, di mana pihak yang diajak wawancara dimintai pendapat dan ide- idenya" (Sugiyono, 
2014:73).

Teknik keabsahan data yang digunakan dalam penelitian ini adalah triangulasi. Sugiyono (2014:125) menjelaskan bahwa triangulasi adalah pengecekan data dari berbagai sumber dengan berbagai cara, dan berbagai waktu. Ada tiga jenis triangulasi yaitu triangulasi sumber, triangulasi teknik pengumpulan data, dan triangulasi waktu (Sugiyono, 2014:125). Penelitian ini menggunakan triangulasi sumber, yaitu "menguji kredibilitas data yang dilakukan dengan cara mengecek data yang telah diperoleh melalui beberapa sumber" (Sugiyono, 2014:127).

Teknik analisis data yang digunakan dalam penelitian ini adalah analisis data Spradley. Tahapan analisisnya adalah analisis domain dan analisis komponensial.

Analisis domain digunakan untuk mengetahui gambaran umum mengenai penerapan PSAK Syariah pada penyajian laporan keuangan di koperasi syariah menurut perspektif praktisi, akademisi, regulator, dan penyusun standar regulasi. Analisis komponensial pada penelitian ini dilakukan untuk mengidentifikasi kontras atau perbedaan jawaban antar masing- masing persepektif mengenai penerapan PSAK Syariah pada penyajian laporan keuangan di koperasi syariah.

\section{HASIL DAN PEMBAHASAN}

Format penyajian laporan kevangan untuk koperasi syariah adalah kerangka laporan keuangan menggunakan PSAK Syariah 101, sementara pencatatan transaksinya mengacu pada PSAK Syariah

102-110 dan SAK ETAP untuk transaksi yang tidak diatur dalam PSAK Syariah. Faktanya, format penyajian laporan keuangan yang dipahami dan dipraktekkan oleh BMT MUDA dan KJKS BMT Amanah Ummah adalah kerangka penyajian laporan keuangan menggunakan format SAK ETAP sementara pencatatan transaksinya mengacu pada PSAK Syariah dan SAK ETAP.

Selain itu, standar akuntansi yang berlaku bagi koperasi syariah sebagai entitas syariah adalah PSAK Syariah untuk transaksi syariah serta SAK ETAP untuk transaksi yang tidak diatur dalam PSAK Syariah. Menurut Peraturan Menteri Negara Koperasi dan UKM nomor 4 tahun 2012 tentang pedoman umum akuntansi koperasi, standar akuntansi yang berlaku bagi koperasi syariah adalah

\section{SAK ETAP.}

Untuk jenis laporan keuangan yang wajib disusun oleh koperasi syariah menurut Peraturan Menteri Negara Koperasi dan UKM nomor 4 tahun 2012 ada lima yaitu: laporan neraca, laporan perhitungan hasil usaha, laporan arus kas, laporan perubahan ekuitas, serta catatan atas laporan keuangan. Untuk laporan dana ZISWAF 
dibuat tersendiri oleh BMT MUDA dan

KJKS BMT Amanah Ummah tanpa

dilaporkan kepada dinas koperasi.

Berikut ini tabel analisis domain dan komponensial:

Tabel 1.

Analisis Domain dan Komponensial

\begin{tabular}{|c|c|c|c|}
\hline \multirow[b]{2}{*}{ No } & \multirow[b]{2}{*}{$\begin{array}{l}\text { Analisis } \\
\text { Domain }\end{array}$} & \multicolumn{2}{|c|}{ Analisis Komponensial } \\
\hline & & BMT MUDA & $\begin{array}{l}\text { KJKS BMT AMANAH } \\
\text { UMMAH }\end{array}$ \\
\hline 1. & $\begin{array}{l}\text { Format } \\
\text { Penyajian } \\
\text { Laporan } \\
\text { Keuangan }\end{array}$ & $\begin{array}{l}\text { Kerangka laporan keuangan } \\
\text { menggunakan SAK ETAP } \\
\text { sementarar pencatatan } \\
\text { transaksinya menggunakan } \\
\text { PSAK Syariah }\end{array}$ & $\begin{array}{l}\text { Kerangka laporan } \\
\text { keuangan menggunakan } \\
\text { SAK ETAP sementara } \\
\text { pencatatan transaksinya } \\
\text { menggunakan PSAK } \\
\text { Syariah }\end{array}$ \\
\hline 2. & $\begin{array}{l}\text { Standar } \\
\text { Akuntansi } \\
\text { Keuangan } \\
\text { yang } \\
\text { Berlaku }\end{array}$ & $\begin{array}{l}\text { Tetap menggunakan PSAK } \\
\text { Syariah sementara SAK } \\
\text { ETAP untuk format laporan } \\
\text { keuangan saja }\end{array}$ & $\begin{array}{l}\text { PSAK Syariah sementara } \\
\text { SAK ETAP hanya } \\
\text { digunakan untuk kerangka } \\
\text { laporan keuangan saja }\end{array}$ \\
\hline 3. & $\begin{array}{l}\text { Jenis } \\
\text { Laporan } \\
\text { Keuangan } \\
\text { yang } \\
\text { Wajib } \\
\text { Disusun }\end{array}$ & $\begin{array}{l}\text { Arus kas, } \\
\text { perhitungan hasil usaha, } \\
\text { perubahan modal, dan } \\
\text { catatan atas laporan } \\
\text { keuangan serta laporan } \\
\text { keuangan lain mengikuti } \\
\text { permintaan nasabah }\end{array}$ & $\begin{array}{l}\text { Arus kas, neraca, } \\
\text { perhitungan hasil usaha, } \\
\text { perubahan modal, dan } \\
\text { catatan atas laporan } \\
\text { keuangan }\end{array}$ \\
\hline
\end{tabular}

Sumber: Hasil Penelitian Diolah

Berdasarkan tabel 4.1 format penyajian laporan keuangan KJKS yang telah disepakati oleh kedua lembaga KJKS di atas, menggunakan format SAK ETAP. Namun mereka tetap berpendapat bahwa standar akuntansi keuangan yang berlaku untuk KJKS adalah PSAK Syariah, sementara SAK ETAP hanya berfungsi sebagai kerangka laporan keuangan.

Jenis laporan keuangan yang wajib disusun oleh KJKS, BMT MUDA hanya menyusun dua laporan keuangan yaitu laporan neraca dan laporan perhitungan hasil usaha. Sisanya mengikuti permintaan dari nasabah jika nasabah menginginkan laporan keuangan yang lain. Sementara itu, KJKS BMT Amanah Ummah menyusun lima laporan kevangan yaitu laporan neraca, laporan perhitungan hasil usaha, laporan arus kas, laporan perubahan ekuitas, dan catatan atas laporan keuangan. Kesimpulannya adalah laporan akhir tahun yang biasa mereka susun ada lima yaitu laporan neraca, laporan perhitungan hasil usaha, laporan arus kas, laporan perubahan ekuitas, dan catatan atas laporan keuangan. Hal ini berdasarkan pernyataan mereka bahwa saat pengauditan laporan keuangan mereka hanya mengaudit kelima laporan kevangan tersebut karena menurut mereka kelima laporan keuangan itulah yang wajib dibuat jika mengacu pada standar akuntansi kevangan ETAP.

Berdasarkan hasil analisis di atas, menunjukkan bahwa ada satu fenomena yang menyebabkan laporan keuangan KJKS kurang sesuai dengan PSAK Syariah yaitu pedoman penyajian laporan keuangan KJKS cenderung menggunakan pedoman standar akuntansi keuangan ETAP. Hal ini sesuai dengan Peraturan Menteri Negara Koperasi dan Usaha Kecil dan Menengah RI nomor 4 tahun 2012 tentang pedoman umum akuntansi koperasi yang menyatakan bahwa standar akuntansi keuangan yang berlaku untuk koperasi adalah SAK ETAP. Bab 1 peraturan tersebut menyebutkan bahwa:

Standar akuntansi keuangan yang mengacu pada IFRS 
dikelompokkan menjadi 2 (dua) yaitu Standar Akuntansi Keuangan Entitas Tanpa Akuntabilitas Publik (SAK ETAP) dan Standar Akuntansi Keuangan Umum (SAK Umum). Mengingat koperasi sejauh ini termasuk dalam entitas tanpa akuntabilitas publik, maka memberlakukan akuntansi koperasi dengan SAK ETAP.

Peraturan ini juga menetapkan bahwa bentuk, isi penyajian, dan pengungkapan laporan keuangan koperasi mengacu pada SAK ETAP. Berikut pernyataannya:

Pedoman ini menetapkan bentuk, isi penyajian, dan pengungkapan laporan keuangan koperasi untuk kepentingan internal koperasi maupun pihak lain selaku pengguna laporan keuangan koperasi. Pedoman ini merupakan acuan yang harus dipatuhi oleh koperasi dan aparat dalam melakukan pembinaan dalam menyusun laporan keuangan.

Peraturan ini berlaku untuk semua koperasi di Indonesia, tanpa terkecuali Koperasi Jasa Keuangan Syariah, mengingat KJKS berada di bawah naungan Dinas Koperasi. Berikut pernyataannya:

Pedoman umum akuntansi koperasi sebagaimana dimaksud dalam Pasal 1 merupakan acuan bagi koperasi di Indonesia, dan pembina koperasi pemerintah, pemerintah provinsi, kabupaten dan/kota serta pihakpihak lain yang terkait. Khusus untuk usaha simpan-pinjam, akuntansi koperasi diatur sendiri.

Berikut tabel analisis penyajian laporan keuangan koperasi syariah:
Tabel 2.

Analisis Penyajian Laporan Kevangan

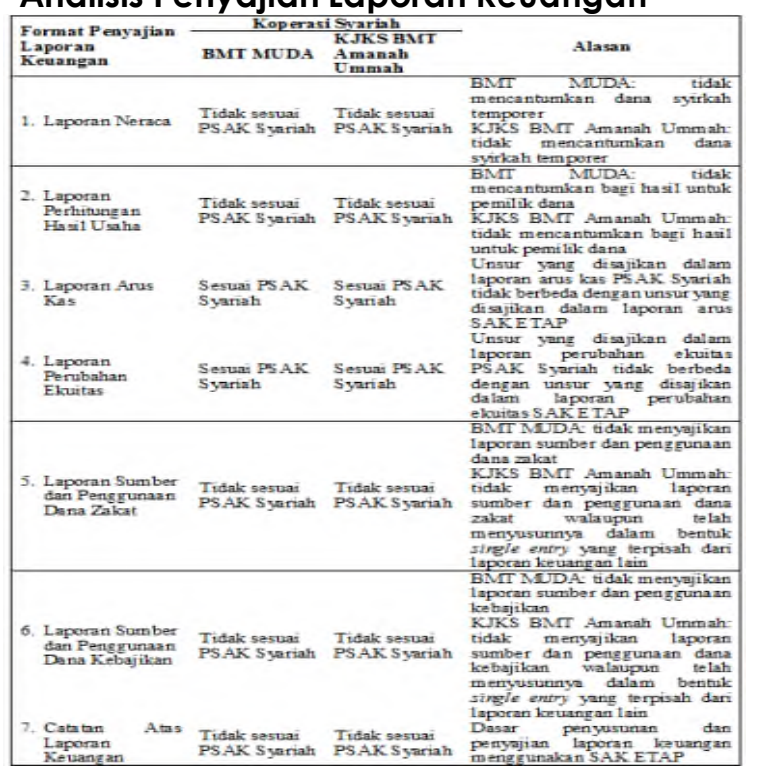

Sumber: Hasil Penelitian Diolah

Berdasarkan tabel 4.2 ada dua jenis laporan keuangan yang sesuai dengan PSAK Syariah yaitu laporan arus kas dan laporan perubahan ekuitas. Hal ini dikarenakan tidak ada perbedaan format penyajian dua laporan kevangan tersebut dalam PSAK Syariah maupun SAK ETAP. Sementara itu hasil analisis penyajian dari laporan neraca, laporan perhitungan hasil usaha, laporan sumber dan penggunaan dana zakat, laporan sumber dan penggunaan dana kebajikan, serta catatan atas laporan keuangan, menunjukkan adanya ketidaksesuaian dengan penyajian di PSAK Syariah. Ketidaksesuaian penyajian laporan neraca terletak pada tidak dicantumkannya dana syirkah temporer. Ketidaksesuaian penyajian laporan perhitungan hasil usaha terletak pada tidak dicantumkannya bagi hasil untuk pemilik dana. Ketidaksesuaian penyajian laporan sumber dan 
penggunaan dana zakat dan laporan sumber dan penggunaan dana kebajikan karena kedua lembaga koperasi syariah tidak menyusun dua laporan keuangan tersebut. Ketidaksesuaian penyajian catatan atas laporan kevangan dikarenakan dasar penyusunan dan penyajian laporan keuangan yang digunakan oleh dua lembaga tersebut adalah SAK ETAP.

Hasil analisis di atas membuktikan bahwa penyajian laporan keuangan koperasi syariah menggunakan pedoman SAK ETAP. Hal ini tentu bertentangan dengan PSAK Syariah 101 tentang penyajian laporan kevangan syariah. Paragraf 1 dalam PSAK Syariah 101 menyebutkan bahwa jika suatu lembaga keuangan syariah merupakan entitas syariah maka standar akuntansi keuangan yang berlaku untuk pengakuan, pengukuran, penyajian, dan pengungkapan transaksi adalah PSAK Syariah. Berikut pernyataanya:

1. Pernyataan ini bertujuan untuk mengatur penyajian dan pengungkapan laporan keuangan untuk tujuan umum (general purpose financial statements) untuk entitas syariah yang selanjutnya disebut "Iaporan kevangan", agar dapat dibandingkan baik dengan laporan keuangan entitas syariah periode sebelumnya maupun dengan laporan kevangan entitas syariah lain. Pengakuan, pengukuran, penyajian, dan pengungkapan transaksi dan peristiwa tertentu diatur dalam Pernyataan Standar Akuntansi Keuangan (PSAK) terkait.

Entitas syariah adalah entitas yang melaksanakan transaksi syariah sebagai kegiatan usaha berdasarkan prinsipprinsip syariah yang dinyatakan dalam anggaran dasarnya (IAI, 2009: 101.1).

Wiroso (2011: 20) dalam bukunya "Akuntansi Transaksi Syariah", menjelaskan bahwa:

Akuntansi industri khusus seperti akuntansi koperasi syariah, harus menerapkan PSAK yang berlaku umum dan PSAK khusus karena entitas tersebut memiliki karakter khusus yang tidak dapat disampaikan dengan entitas yang lain.

Sehingga akuntansi koperasi syariah menggunakan standar akuntansi PSAK Syariah, SAK ETAP, dan peraturan dari Departemen Koperasi.

Porsi penggunaan 2 standar kevangan itu dalam pelaporan keuangan adalah kerangka penyajian laporan kevangan tetap mengacu pada PSAK Syariah 101, transaksi syariahnya mengacu pada PSAK Syariah 102-110, sedangkan akun-akun lain yang tidak diatur PSAK Syariah, mengacu pada SAK ETAP atau SAK Umum.

Intinya adalah pengakuan,
pengukuran, penyajian, dan
pengungkapan akuntansi koperasi
syariah tetap mengacu pada PSAK
Syariah, sementara SAK ETAP hanya
berfungsi sebagai pedoman bagi
transaksi- transaksi yang tidak diatur
dalam PSAK Syariah, sehingga laporan


keuangan yang wajib disusun oleh koperasi syariah ada delapan yaitu laporan neraca, laporan perhitungan hasil usaha, laporan perubahan ekuitas, laporan perubahan dana investasi terikat, laporan rekonsiliasi pendapatan dan bagi hasil, laporan sumber dan penggunaan dana zakat, serta laporan sumber dan penggunaan dana kebajikan.

Hal ini sesuai dengan pernyataan Wiroso (2011:49-50) bahwa unsur dari laporan kevangan entitas syariah terdiri dari:

a. Komponen laporan kevangan yang mencerminkan kegiatan komersial, seperti: laporan posisi keuangan, laporan laba rugi, laporan arus kas, dan laporan perubahan ekuitas.

b. Komponen laporan keuangan yang mencerminkan kegiatan sosial, seperti: laporan sumber dan penggunaan dana zakat serta laporan sumber dan penggunaan dana kebajikan.

c. Komponen laporan keuangan lainnya yang mencerminkan kegiatan dan tanggung jawab khusus entitas syariah tersebut.

Faktanya, pengakuan, pengukuran, dan pengungkapan akuntansi koperasi syariah menggunakan pedoman PSAK Syariah, sementara penyajian laporan keuangan koperasi syariah menggunakan pedoman SAK ETAP.

Dampaknya adalah laporan keuangan yang disusun oleh koperasi syariah mengikuti pedoman SAK ETAP, yaitu laporan neraca, laporan, laporan perhitungan hasil usaha, laporan perubahan ekuitas, laporan arus kas, dan catatan atas laporan keuangan. Bab 3 paragraf 3.12 Standar Akuntansi Keuangan ETAP menjelaskan bahwa laporan kevangan entitas meliputi:

a. Neraca;

b. Laporan laba rugi;

c. Laporan perubahan ekuitas yang juga menunjukkan:

i. seluruh perubahan dalam ekuitas, atau

ii. perubahan ekuitas selain perubahan yang timbul dari transaksi dengan pemilik dalam kapasitasnya sebagai pemilik;

d. Laporan arus kas; dan

e. Catatan atas laporan keuangan yang berisi ringkasan kebijakan akuntansi yang signifikan dan informasi penjelasan lainnya.

(IAI, 2009: 17)

Sementara laporan keuangan yang mencerminkan kegiatan sosial, seperti laporan sumber dan penggunaan dana zakat serta laporan sumber dan penggunaan dana kebajikan, dibuat secara terpisah dari laporan kevangan lain.

Berdasarkan hasil analisis di atas dapat disimpulkan bahwa kurang sesuainya laporan kevangan koperasi syariah terhadap PSAK Syariah disebabkan adanya regulasi dari kementrian koperasi, yaitu peraturan menteri nomor 4 tahun

2012 tentang pedoman umum akuntansi koperasi yang memberlakukan SAK ETAP sebagai pedoman umum akuntansi bagi semua koperasi di Indonesia, termasuk koperasi syariah, sehingga mereka cenderung menggunakan SAK ETAP saat penyajian laporan kevangan untuk memenuhi aspek kepatuhan terhadap aturan yang telah dikelvarkan 
oleh kementrian koperasi.

Jika melihat teori bangun prinsip akuntansi syariah yang ditulis oleh Wiroso dalam bukunya "Akuntansi Syariah", dapat disimpulkan pula bahwa koperasi syariah cenderung menggunakan landasan operasional tingkat dua dari bangun prinsip akuntansi syariah, yaitu peraturan pemerintah untuk industri (regulasi), saat penyajian laporan kevangan. Padahal Wiroso (2011: 20) menyebutkan bahwa landasan operasional akuntansi syariah di Indonesia terdiri dari tiga tingkatan yaitu: tingkat pertama bersumber dari PSAK Syariah dan PSAK Umum, tingkat kedua bersumber dari SAK Internasional negara lain yang sesuai syariah, buletin teknis, peraturan pemerintah untuk industri (regulasi), serta pedoman atas praktek akuntansi industri (Asosiasi Syariah), serta tingkat ketiga bersumber dari praktek konvensi dan kebiasaan pelaporan yang sehat sesuai syariah, pendapat ahli, hasil penelitian, buku dan teks.

Mengacu pada teori di atas, seharusnya koperasi syariah menggunakan landasan operasional tingkat 1 yang berisi PSAK Syariah dan SAK ETAP sebagai pedoman penyajian laporan kevangan. Koperasi syariah tidak seharusnya menjadikan landasan operasional tingkat dua, yaitu peraturan menteri nomor 4 tahun 2012 sebagai pedoman penyajian laporan keuangan. Hal ini sesuai dengan penjelasan Wiroso (2011: 21) bahwa kerangka bangun prinsip akuntansi syariah digambarkan sebagai suatu bangunan rumah 'Prinsip Akuntansi Syariah yang Berlaku Umum di Indonesia' dimana setiap lapisan di bawahnya menjadi landasan bagi lapisan di atasnya.

\section{SIMPULAN}

Kesimpulan dari penelitian ini adalah kurang sesuainya penyajian laporan keuangan koperasi syariah terhadap PSAK Syariah disebabkan adanya regulasi dari kementrian koperasi, yaitu peraturan menteri nomor 4 tahun 2012 yang memberlakukan SAK ETAP sebagai pedoman umum akuntansi bagi semua koperasi di Indonesia, termasuk koperasi syariah, sehingga mereka cenderung menggunakan SAK ETAP saat penyajian laporan keuangan untuk memenuhi aspek kepatuhan terhadap aturan yang telah dikeluarkan oleh kementrian koperasi. Selain itu, saat penyajian laporan kevangan, koperasi syariah cenderung menggunakan landasan operasional tingkat dua yang berisi peraturan menteri nomor 4 tahun 2012 daripada landasan operasional tingkat satu yang berisi PSAK Syariah dan SAK ETAP, dari teori bangun prinsip akuntansi syariah yang berlaku umum di Indonesia.

Dampaknya adalah penyajian laporan keuangan di koperasi syariah kurang memenuhi unsur-unsur laporan kevangan entitas syariah, seperti yang tercantum dalam PSAK Syariah 100 yang berisi Kerangka Dasar Penyusunan 
Nabilah, et al/Jurnal Ekonomi Syariah Teori dan Terapan Vol. 3 No. 10 Oktober 2016: 843-855; ANALISIS PENYAJIAN LAPORAN KEUANGAN KOPERASI SYARIAH (Studi Kasus Pada BMT MUDA dan KJKS BMT Amanah Ummah di Surabaya)

dan Penyajian Laporan Keuangan Syariah (KDPPLKS).

\section{DAFTAR PUSTAKA}

Buchori, Nur S. 2009. Koperasi Syariah. Sidoarjo: Mashun

Dewan Standar Akuntansi Keuangan. 2009. Pernyataan Standar Akuntansi Keuangan. Jakarta: Ikatan Akuntan Indonesia

Harahap, Sofyan Syafri. 2011. Teori Akuntansi. Jakarta: PT RajaGrafindo Persada

Keputusan Menteri Negara Koperasi dan Usaha Kecil dan Menengah Republik Indonesia Nomor 91 Tahun 2004 tentang Petunjuk Pelaksanaan Kegiatan Usaha Koperasi Jasa Keuangan Syariah, (Online), (http://www.kumkm- sulsel.info/regulasikeputusan-menteri, diakses 27 Agustus 2014, pukul 09.34)

Peraturan Menteri Negara Koperasi dan Usaha Kecil dan Menengah Republik Indonesia Nomor 35 Tahun 2007 , (Online), (http://www.smecda.com/Files/Dep_ Pembiayaan/11_Permen_No_35.3_X_T hn_2007.pdf, diakses 27 Agustus 2014, pukul 09.38)

Peraturan Menteri Negara Koperasi dan Usaha Kecil dan Menengah Republik Indonesia Nomor 39 Tahun 2007 tentang Pedoman Pengawasan Koperasi Jasa Keuangan Syariah dan Unit Jasa Keuangan Syariah Koperasi, (Online), (http://www.depkop.go.id, diakses 27 Agustus 2014, pukul 09.55)

Peraturan Pemerintah Nomor 9 Tahun 1995 tentang Pelaksanaan Kegiatan Usaha Simpan Pinjam Oleh Koperasi, (Online), (http://www.depkop.go.id, diakses 27 Agustus 2014, pukul 09.49)

Sari, Tika Wahyu Puspita. 2014. Analisis Struktur dan Komponen Laporan Kevangan KJKS UGT Sidogiri Wirolegi, (Online), (http://repository.unej.ac.id, diakses 16 Oktober 2014, pukul 07.52)

Sholihah, Siti. 2009. Analisis Penerapan PSAK No 101-106 Dalam Akuntansi Syariah (Studi Kasus KJKS AN NISA Kabupaten Pemalang (Online), (http://library.walisongo.ac.id/digilib/ gdl.php, diakses 16 Oktober 2014, pukul 08.15)

Sugiyono. 2014. Memahami Penelitian

Kualitatif. Bandung: Alfabeta

Undang-Undang Republik Indonesia Nomor

25 Tahun 1992 tentang Perkoperasian, (Online), (http://portal.mahkamahkonstitusi.go. id/eLaw/download_pdf.php, diakses 27 Agustus 2014, pukul 09.26)

Wiroso. 2011. Akuntansi Transaksi Syariah. Jakarta: IAI

Yin, Robert K. 1996. Studi Kasus Desain \& Metode. Terjemahan oleh M. Djauzi Mudzakir. 2011 Jakarta: Rajawali Pers 